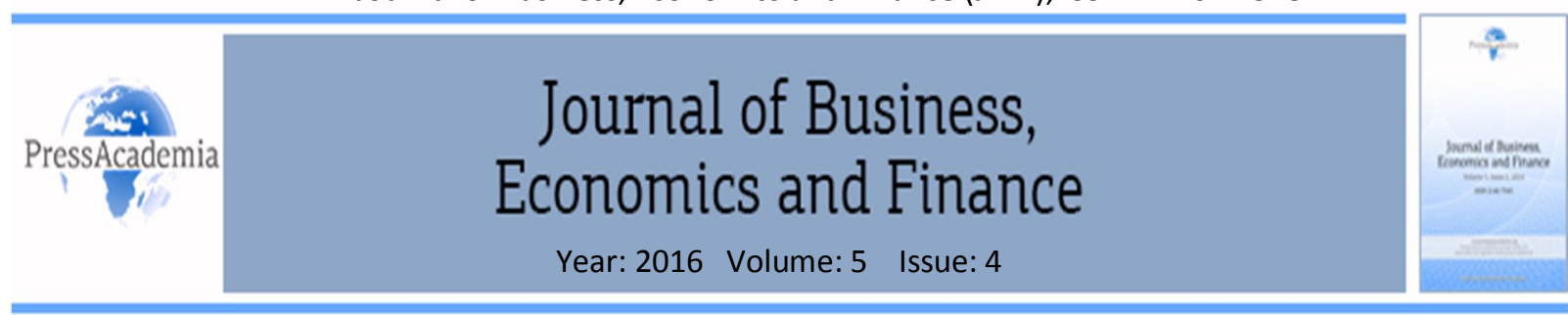

\title{
DETERMINANTS OF NON-PERFORMING LOANS OF DEPOSIT BANKS IN TURKEY
}

\section{DOI: 10.17261/Pressacademia.2017.356}

\author{
Ozcan Isik ${ }^{1}$, Suleyman Bolat ${ }^{2,3}$ \\ ${ }^{1}$ Cumhuriyet University. ozcan@live.com \\ ${ }^{2}$ Aksaray University. bolatsuleyman80@gmail.com \\ ${ }^{3}$ University of Exeter. s.bolat@exeter.ac.uk
}

\begin{abstract}
This study empirically analyzes the factors that determine the non-performing loans (so-called bad loans) of 20 deposit banks in Turkey for 2006-2012 period using panel data analysis method. The analysis results reveal that solvency, profitability, credit quality, diversification, economic growth and the recent financial crisis are essential indicators of non-performing loans rate in Turkish banking sector. More specifically, greater profitability and revenue diversification significantly lowers non-performing loans rate, whereas greater capital and loan loss provisions significantly increase non-performing loans rate. In terms of macroeconomic variables, only economic growth has a negative effect on the non-performing loans (NPLs) ratio. Moreover, our results also uncover that deposit banks' NPLs ratio increases during the latest global financial turmoil period.
\end{abstract}

Keywords: Deposit banks, non-performing loans, panel data analysis, credit risk, Turkey.

JEL Classification: B22, C23, E44.

\section{INTRODUCTION}

The issue related to the relationship between the non-performing loans (NPLS) and bank-specific and macroeconomic conditions has drawn great deal of attention in the recent decades, because of results that the NPLs have on both banking system and the economy (Reinhart and Rogoff, 2011; Louzis et al. 2012; Castro, 2013; Makri et al. 2014; Chaibi and Ftiti, 2015; among others). The one of the main problems of the banking sector is the deterioration of the quality of the loan in asset side of balance sheet in banks in many bank-based financial systems (Demirguc-Kunt, 1989). Actually, the NPLs, a measure of both loan risk and asset quality, are signal for the deteriorating of banks' balance sheet and it is typically a pioneer for banking sector crisis and associated with fragility of the financial system. Potential increases in the amount of bad loans in the loan portfolio may cause banks to have difficulty in their financial intermediation process and this severely influences their liquidity and profitability. If the increases in loan defaults are not controlled, banking failures are inevitable (Bardhan and Mukherjee, 2016; Ghosh, 2015; Kasman and Kasman, 2015; Nkusu, 2011). Likewise, banks' asset quality deterioration could decelerate economic growth by weakening the stability of banking system (Ghosh, 2015; Zeng, 2012). But then, NPLs could be employed to mark the onset of a banking crisis and to test the vulnerability of the financial system (Sorge, 2004; Reinhart and Rogoff, 2011). Researchers have claimed that macroeconomic conditions can affect credit market and financial stability in the last decade. So, macroeconomic environment can be seen as one of the most important determinants of banking credit risk (Demirguc-Kunt and Detragiache, 1998; Castro, 2013; Messai and Jouini, 2013; Skarica, 2014; among others). As well as macroeconomic conditions, bank specific indicators are also used in many previous banking studies to explore the determinants of NPLs (Us, 2016; Abdioglu and Aytekin, 2016; Bardhan and Mukherjee, 2016; Dimitrios et al., 2016; Ghosh, 2015; Berger and DeYoung, 1997; among others). 
We intend to understand this link between the macroeconomic developments, specific banking variables and the NPLs for Turkish banking industry in this paper. Our study contributes to the existing banking literature by investigating strictly regulated banking industry in Turkey. More specifically, as far as we know, our study is the first to examine the link between unemployment rate and income diversification and NPLs for Turkish banking system. Second contribution of our study is methodological. We lagged all of bank-specific variables by one year to cope with endogeneity issue in the traditional panel data models, i.e., the pooled-OLS, fixed-effects (FEs) and random effects (REs) models. Thirdly, because of the fact that the sample time period (2006-2012) we have selected contains the latest global economic crisis, the influence of this crisis on NPLs of Turkish deposit banks is also analyzed by way of a dummy crisis variable. Estimation results obtained from our study seem to imply that bank capitalization and loan loss provisions exert positive and significant influence on the NPLs, whereas profitability and income diversification are negatively associated with the NPLs. As for the impact of macroeconomic indicators, the results show that while there is a negative and significant relationship between economic growth and the NLPs, unemployment and inflation rate have no significant effect on the NPLS of deposit banks. The rest of this study is organized as follows. Section 2 overviews the literature review, our data and methodology used are presented in sections 3 and 4, respectively. Section 5 presents the empirical results and finally we present our conclusions in section 6 .

\section{LITERATURE REVIEW}

There are lots of empirical studies which examine the effect of banking sector factors and macroeconomic determinants on the non-performing loans. Berger and DeYoung (1997) investigate four bank managementrelated hypotheses, which are related to the link among loan quality, cost efficiency and bank capital using Granger-causality techniques. Their results shows the bad management and moral hazard hypotheses were explaining an important part of the bad loans. Based on a sample of 46 banks from 12 countries in the MENA region during 2002-2006, Boudriga et al. (2009) examine how bank specific, institutions and business environment and macroeconomic environment indicators influence on the rate of the NPLs in the MENA region employing a random effects regression analysis. They report that the institutional environment, bank capital, loan loss provisions, credit growth, foreign participation are significantly associated with problem loans. Using a sample of 9 Greek deposit banks between the years 2003:Q1-2009:Q3, Louizis et al. (2012) analyze the factors influencing the ratio of the NPLs using the Blundell-Bond system GMM estimator. According to empirical results, They conclude that economic growth, the unemployment, public debt, and interest rate and profitability measured by ROE have a considerable influence on the ratio of NPLs of Greek banks for all loan classes (i.e. business, consumer and mortgage loans).The relationship between the macroeconomic variables and the banking credit risk measured by the ratio of non-performing loans to total loans in 5 European countries (namely, Greece, Ireland, Italy, Portugal and Spain) between 1997:Q1 and 2011:Q3 is investigated by Castro (2013) using dynamic panel data approaches. The empirical findings suggest that the credit risk represented by NPLs is negatively and significantly correlated with GDP growth, the share price indices and the housing prices, whereas it is positively and significantly correlated with the unemployment rate, interest rate, real exchange rate, and credit growth. Moreover, the author observes a considerable rise in the NPLs during the latest economic crisis period. Exploring the effects of macroeconomic indicators on the ratio of the NPLs in the $28 \mathrm{EU}$ countries over the period of 2000-2013, Angela and Irina (2013) find that the real GDP growth rate, unemployment, domestic credit, government budget balance, and public debt are statistically significant in NPLs equations. Curak et al. (2013) empirically examine determinants of NPLs using a sample of 69 banks from 10 different countries in the banking industry of Southeastern Europe during 2003-2010. The results obtained from GMM estimation indicate that the credit risk measured by the NPLs ratio is influenced by bank-specific indicators like bank size, profitability measured by the ratio of net income to total assets and bank capital. Moreover, the NPLs ratio is affected by macroeconomic indicators such as economic growth, inflation and interest rate. Based on panel data for 9 Central, Eastern and Southeastern European (CESEE) countries over the period 2004-2012, Jakubik and Reininger (2013) study the determinants of the NPLs by using GMM estimations. They find that real GDP growth and national stock price index reduce the level of the NPLs, while a nation's exchange rate, private credit-to-GDP and past NPLs increase present period's NPLs. Messai and Jouini (2013) examine the issue for 85 banks that contain Italy, Greece and Spain, respectively, over the period from 2004 to 2008. They report that economic growth and bank profitability decrease the NPLs ratio, whereas real 
interest rates, unemployment rates, and the quality of poor credit affect NPLs of banks positively. Using data of Eurozone's banking systems over 2000-2008, Makri et al. (2014) test the factors driving the NPL ratio in 14 different countries by using difference GMM estimation. They conclude that reveal strong correlations between ratio of the NPLs and various macroeconomic factors such as economic growth, public debt and unemployment and bank-specific indicators such as past NPLs rate, bank capital, and profitability measured by return on equity. Skarica (2014) explores the macroeconomic factors affecting the level of the NPLs using a fixed effects estimator for quarterly data for the period of 2007-2012 in 7 Central and Eastern European countries. The empirical results suggest both unemployment and inflation increase the development of NPLs, while real GDP growth has a negative effect on the NPLs. In a study on the French (market-based economy) and German (bank-based economy) banking industry, Chaibi and Ftiti (2015) empirically analyses what determines the non-performing loans of commercial bank operating in both economies belong to the same euro area for the period of 2005-2011 by using GMM and Roodman estimations. According to dynamic panel regressions results, Lagged NPLs' ratio, Loan loss provisions, Inefficiency, leverage, bank size, profitability represented by ROE are significant bank-specific determinants of NPLs. Their findings also show that for the inflation, GDP growth, Interest rate, unemployment, and exchange rate are significant macro-economic drivers of NPLs. Based on data of commercial banks from 15 euro-area countries for the period 1990:Q1-2015:Q2, Dimitrios et al. (2016) investigate the main determinants of non-performing loans by employing GGM estimator. Their empirical study is the first empirical study which investigates the role of taxation on the personal income and the output gap. They report that past NPLs, ratio of loans to deposits, profitability, unemployment, economic growth, debt, taxation and output gap are the main determinants of NPLs. In Indian banking sector between the years 1995-2011, Bardhan and Mukherjee (2016) focus on analyzing the effect of bank-specific indicator on the non-performing assets (NPAs) by using the System GMM technique. They report that the NPAs, bank size, inflation, and exchange rate in the next period influence the current NPAs positively, while bank capital, profitability, GDP growth in the next period influence the current NPAs negatively.

Other hand, there are several studies which investigate the effect of banking sector factors and macroeconomic determinants on the non-performing loans in Turkish literature. On Turkish banking system, İskenderoğlu and Tomak (2013) make an analysis that contains 15 deposit banks between the years 2002-2012 by using GMM estimator. They conclude that increases in the ratio of fixed assets to total asset and past NPLS are associated with a higher level of non-performing loans. Using static and dynamic models, Vardar (2015) finds that bank specific (size, liquidity, Lending, the ratio of off-balance sheet items to total assets) and macroeconomic indicators (growth of GDP and interest rate) are leading determinants of the rate of NPL of deposit banks for the period from 2002 to 2012. Investigating what determines the NLP rate of 26 Turkish deposit banks between 2002-Q4 and 2013-Q1, Yağcılar and Demir (2015) find that being listed in stock market, bank size, loans-to- total deposits ratio, liquidity risk and profitability. They are negatively associated with the NPLs, whereas foreign banks dummy variable, bank capital, economic growth and interest rates are positively related to the NPLs. Another study from Turkish banking industry, Kasman and Kasman (2015) report that economic growth, the ratio of loans to total assets bank size and the 2008 financial crisis are main determinants of NPLs over the period 2002-2012 in a recent study by Us (2016), analyzing the determinants of non-performing loans of deposit banks before and after the global economic crisis over the period from 2002 Q 4 to 2015Q4. The author reports that the NPLs rate is mostly influenced by bank-specific indicators before the crisis. However, the influences of these indicators disappear after the crisis. Besides, the association between bank-specific and macroeconomic factors and NPLs of 22 commercial banks from Turkey between the years 2002 to 2014 is explored in another recent study by Abdioglu and Aytekin (2016). Authors conclude that while past NPLs, net interest margin, capital adequacy ratio and bank capital have negative influences on NPLs, the ratio of loans to deposits using dynamic panel estimators in their study. The ratio of other operating expenses to total operating revenue, interest applied to loans and non-interest income-to-total assets ratio has positive influences on NPLs.

\section{DATA}

Following Us (2016), Chaibi and Ftiti (2015), Makri et al. (2014) and Curak et al. (2013), non-performing loans (NLPs), dependent variable, is calculated as the ratio of non-performing loans (gross) to total loans. Some Independent variables such as macroeconomic and bank-specific variables commonly employed in studies 
regarding non-performing loans are included in the analysis. Our study includes the size of banks (BS) variable in our models to investigate the link between bank size and NPLs. Larger banks have more resources to make risk assessment efficiently, which resulting in dampening of asymmetric information. Additionally, larger banks having better diversification opportunities may also engage in more risky activities (Curak et al., 2013; BaselgaPascual et al. 2015). As a consequence, we expect that the size has a positive influence on the NPLs of banks. Equity capital (EQTA) calculated as the ratio of shareholders' equity to total assets is regarded as banks' internal strength to absorb a variety of shocks especially during unstable macroeconomic conditions. Lower capitalized banks are more likely to take more risky credit activities, which ends up with an increase in problem loans (Makri et al., 2014; Ghosh, 2015). The ROA employed in this study as a profitability measure is considered as an important bank-specific determinant of ratio of the NPLs. The level of profitability in banks is influenced by their risk-taking behavior. Banks with more profitability tends to have less incentive to engage in more risky lending activities than the optimal level, leading to higher NLPs (Louzis et al., 2012; Curak et al., 2013; Makri et al., 2014; Dimitrios et al. 2016). Therefore, the link between profitability ratio and NPLs ratio is expected to be negative. Lending ratio (LTA) presented by the ratio of loans and receivables to total assets is also one of the investigated bank-specific variables in this study. This ratio is considered to be a crucial driver of credit risk. As the total loans-to-total assets ratio grows faster, conditions concerning credit standard weaken and thus stringent loan contract standards are more likely to end up with a high level of credit risk (Baselga-Pascual et al. 2015; Ghosh, 2015; Us, 2016). As a result, the lending is expected to be positively related to NPLs. We included credit quality variable, which demonstrates the link between credit quality and bad loans. As suggested by Chaibi and Ftiti (2015), predicting high levels of capital loss, banks are more likely to make higher provisions, which results in potentially higher credit risk. Thus problem loans in loans portfolio of banks increase banks' NPLs ratio. A positive relationship between provision for loan losses and NPLs is expected. The other bankspecific variable included in the regression model is income diversification (NII). Banks with diversified assets portfolios are more likely to avoid riskier behavior. Banks' diversification opportunities improve quality of loan and minimize credit risk. Besides, trusting varied types of revenue could cause banks to decline loans opportunities for lower quality borrowers (Hu, Yang and Yung-Ho, 2004; Louzis et al., 2012; Ghosh, 2015). Hence Income diversification variable is expected to exhibit negative association with the NPLs of banks.

With regard to macroeconomic factors used in this study, we used the growth rate of GDP to control for macroeconomic cycle, economic environment and to capture the economic activity of government. We expect a negative effect of the growth of real GDP on NPLs and negatively associated with NPLs in this study. If the economy of a country expands, the income of corporate borrower increases and they have powerful ability to service their loans and debts. The increases of growth rate means that it generally shows the rise of economic and financial stability. Otherwise, if the growth rate of GDP shrinks in an economy, so, credit is widened to lowquality debtors and this situation causes to an increase in NPLs tend in the end (Makri et al. 2014; Vardar, 2015; Ghosh, 2015; Bardhan and Mukherjee, 2016). We also employ the unemployment rate to dominate for macroeconomic cycle and economic environment which defines the behavior of the credit risk. The effect of increase of the unemployment rate on the NPLs is expected to be positive. Firstly, the unemployment cause to decrease the cash flow of households and it leads to make a lower consumption in the economy. Other hand, the unemployment rate also influences firm' cash flow and causes to decline of their production (Louzis et al., 2012; Makri et al. 2014; Chaibi and Fititi, 2015; Dimitrios et al., 2016). Finally it leads fragile debt position and then a rising an unemployment cause to extend in NPLs. Interest rate measured by percentage change of consumer price index is regarded as another macroeconomic driver of NPLS. Theoretically, a rise in interest rate may cause the repayment capacity of borrowers to weaken, which ends up with to a higher level of NPLs rate (Nkusu, 2011; Curak et al., 2013; Castro, 2013; Škarica, 2014; Ghosh, 2015; Bardhan and Mukherjee, 2016). So, we expect that the inflation rate has a positive influence on the NPLs of banks.

\section{METHODOLOGY}

Our goal is to determine the factors that influence non-performing loans rate of Turkish deposit banks for the period of 2006-2012. Our sample contains 20 deposit banks and other deposit banks operating in Turkey are dropped from our sample on account of missing values or inconsistencies. Annual financial data for deposit banks is mostly obtained from the Turkish Banking Association (TBA), the macroeconomic variables, namely inflation rate, economic growth rate and unemployment rate are taken from the Central Bank of the Republic 
of Turkey (CBRT) database. The following econometric model which is similar to that of Ghosh (2015), BaselgaPascual et al. (2015), Makri et al. (2014) and Curak et al. (2013) is used to investigate the factors influencing non-performing loans rate of deposit banks in Turkey:

$\mathrm{NPLs}_{\mathrm{it}}=\alpha_{0}+\alpha_{1} \mathrm{BSV}_{\mathrm{it}-1}+\alpha_{2} \mathrm{MEV}_{\mathrm{t}}+\alpha_{3}$ CRISIS $_{\mathrm{t}}+\mu_{\mathrm{i}}+\epsilon_{\mathrm{it}}$

In this specification, NPLs $s_{i t}$ is the independent variable employed to measure the ratio of non-performing loans of bank $\mathrm{i}$ at year $\mathrm{t}$; $\alpha$ is a constant term; $\mathrm{BSV}_{\mathrm{it}-1}$ donates bank-specific variables; $\mathrm{MEV}_{\mathrm{t}}$ refers to macroeconomic variables; CRISIS $_{t}$ represents a crisis dummy variable that takes the value 1 if the years are equal to 2007, 2008 and 2009, otherwise $0 . \mu_{\mathrm{i}}$ is unknown bank-specific effect and $\epsilon_{\mathrm{it}}$ is a random disturbance; the coefficients $\alpha_{1}, \alpha_{2}$ and $\alpha_{3}$ are the parameters to be estimated. Furthermore, all bank-specific variables are lagged by one year to address endogeneity issue. The definition and summary statistics for the variables employed in Equation (1) to explore the association between bank-specific and macroeconomic indicators and NPLs in Turkish banking system are presented in Table 1, Table 2 and Table 3, respectively.

Table 1: Definition of the Variables

\begin{tabular}{|c|c|c|}
\hline Name of Variables & Symbol & Description \\
\hline \multicolumn{3}{|c|}{ Panel A: Dependent variable } \\
\hline Non-performing loans & NPLs & Non-performing loans (gross) over total loans \\
\hline \multicolumn{3}{|c|}{ Panel B: Bank-specific variables } \\
\hline Bank size & BS & Natural log of total assets \\
\hline Bank capital & EQTA & Shareholders' equity over total assets \\
\hline Profitability & ROA & Net income over total assets \\
\hline Lending activity & LTA & Total loans and receivables over total assets \\
\hline Credit quality & PLLTA & Provision for loan losses over total assets \\
\hline Revenue diversification & NII & Non-interest income over total assets \\
\hline \multicolumn{3}{|c|}{ Panel C: Macroeconomic variables } \\
\hline Inflation & INF & Annual inflation rate (CPI, year by year \% change) \\
\hline Economic growth & GDP & Annual real GDP growth rate \\
\hline Unemployment & UNEMP & Annual unemployment rate \\
\hline \multicolumn{3}{|c|}{ Panel D: Crisis control variable } \\
\hline Global economic crisis & CRISIS & $\begin{array}{l}\text { Dummy variable that takes the value of } 1 \text { if the years } \\
\text { are } 2007,2008 \text { and } 2009,0 \text { otherwise }\end{array}$ \\
\hline
\end{tabular}

Descriptive statistics for the bank-specific and macro-economic variables employed in this study between the years 2006-2012 are reported in Table 2. The mean (median) of NPLs ratio of banks in our sample is $4.23 \%$ (3.69\%).The maximum value of NPLs ratio is $0.77 \%$, whereas the minimum value of this ratio is $19.27 \%$. In comparison with NPLs in banking sector of some developed and developing countries, the mean value of NPLS ratio for banks in Turkey is relatively smaller when compared to those reported by Bardhan and Mukherjee (2016) for banks in India (4.5\%), Chaibi and Ftiti (2015) for banks in France (5.82\%) and Germany (4.36\%), Ashraf et al. (2016) for banks in Pakistan (12.32\%), Sawada (2013)for banks in Japan (5.77\%) and Hu, Yang and Yung-Ho (2004) for banks in Taiwan (4.76\%).

The mean (median) of BS in our sample banks is 9.6259 (9.7349) with a range between 12.0751 and 6.2653. The mean (median) of EQTA of banks in our sample is $13.27 \%$ (12.3) with a minimum of $6.7 \%$ and a maximum of $49.2 \%$. ROA's mean (median) value is $1.76 \%$ (1.64). While the minimum value of this ratio is $0.49 \%$, the maximum value is $8.02 \%$. The mean (median) of LTA of banks in our sample is $54.32 \%(58.54 \%)$, with a minimum of $3.61 \%$ and a maximum of $76.21 \%$. The mean (median) of sample banks' PLLTA ratio is $1.07 \%$ $(0.9 \%)$, with a range between 0 and $3.8 \%$. On $\mathrm{NII}$, the mean (median) of this variable is $2.29 \%(1.79 \%)$, with a minimum of $2.56 \%$ and a maximum of $22.12 \%$. As far as macroeconomic variables are concerned, the average (median) value of INF, GDP and UNEMP in Turkey is 8.23\% (8.39\%), 3.93\% (4.67), 10.51\% (9.9), respectively. 
Table 2: Descriptive Statistics for Variables

\begin{tabular}{|c|c|c|c|c|c|c|}
\hline Variable & Mean & P50 & $\begin{array}{l}\text { Std. } \\
\text { Dev. }\end{array}$ & Min & Max & $\mathbf{N}$ \\
\hline NPLS & .0423 & .0369 & .0278 & .0077 & .1927 & 133 \\
\hline BS & 9.6259 & 9.7349 & 1.636 & 6.2653 & 12.0751 & 140 \\
\hline EQTA & .1327 & .123 & .0562 & .0670 & .4920 & 140 \\
\hline ROA & .0176 & .0164 & .0119 & -.0049 & .0802 & 140 \\
\hline LTA & .5432 & .5854 & .1551 & .0361 & .7621 & 140 \\
\hline PLLTA & .0107 & .0090 & .0076 & 0 & .0380 & 140 \\
\hline NII & .0229 & .0179 & .0276 & -.0256 & .2212 & 140 \\
\hline CRISIS & .4286 & 0 & .4966 & 0 & 1 & 140 \\
\hline INF & .0823 & .0839 & .0173 & .0616 & .1045 & 140 \\
\hline GDP & .0393 & .0467 & .0466 & -.0483 & .0916 & 140 \\
\hline UNEMP & .1051 & .0990 & .0143 & .0900 & .1270 & 140 \\
\hline
\end{tabular}

Notes: Variable BS represented by banks size is in logarithmic form. See Table 1 for definition of the rest of the variables.

The evolution of the mean values of the bank specific and macroeconomic variable in each year is presented in Table 3. When we look at the means of the variables in Table 3, we see that while the mean values of the NPLs ratio and the PLLTA ratio increase between the years 2007-2009, the mean value of the LTA ratio decreases in the same time period. Both the increases in the NPLs and the PLLTA ratios and the decreases in the LTA ratio are attributable to the global financial crisis, which begins around mid-2007. These results confirm that the latest global economic crisis has increased the level of the NPLs in a large number of developed and developing countries (Makri et al. 2014; Ghosh, 2015; Baselga-pascual et al. 2015). For this reason, we employ the crisis dummy variable in Equation (1) to investigate whether or not the global economic crisis variable has an influence on deposit bank's NPLs ratio.

Table 3: Year-by-Year Mean Values for Variables

\begin{tabular}{llllllllllll}
\hline Year & Obs. & NPLS & BS & EQTA & ROA & LTA & PLLTA & NII & INF & GDP & UNEMP \\
\hline 2006 & 19 & .0352 & 22723.15 & .1123 & .0190 & .4788 & .0091 & .0343 & .0965 & .0217 & .0950 \\
2007 & 20 & .0310 & 26220.40 & .1382 & .0225 & .5413 & .0090 & .0320 & .0839 & .0877 & .0990 \\
2008 & 20 & .0399 & 33070.35 & .1405 & .0165 & .5323 & .0120 & .0231 & .1006 & .0916 & .1270 \\
2009 & 20 & .0669 & 36318.74 & .1450 & .0202 & .5233 & .0188 & .0245 & .0653 & -.048 & .1260 \\
2010 & 20 & .0488 & 45308.05 & .1315 & .0156 & .5574 & .0082 & .0194 & .0640 & .0066 & .1060 \\
2011 & 20 & .0389 & 54955.45 & .1215 & .0117 & .5723 & .0071 & .0131 & .1045 & .0467 & .0900 \\
2012 & 20 & .0366 & 61352.00 & .1423 & .0174 & .5966 & .0111 & .0144 & .0616 & .0689 & .0930 \\
\hline
\end{tabular}

Notes: This table reports the mean values of the bank specific and macroeconomic variables over the sample period. See Table 1 for variable definitions.

\section{FINDINGS AND DISCUSSIONS}

Correlations between dependent and independent variables are reported in Table 4. As reported in Table 4, the correlation matrix of variables used in this study indicates statistically significant correlations between all the regressors and NPLs ratio except for BS, ROA and LTA. More specifically, EQTA, PLLTA and NII are positively and significantly correlated with NPLs. Similarly, the same holds true for UNEMP. The correlation coefficients between NPLs and the other macroeconomic variables (INF and GDP) are negative and statistically significant. BS, ROA and LTA are not significantly associated with NPLs. As shown in Table 4, the maximum sample correlation value is .68, showing that there is no sign of multicollinearity among the regressors. As presented in the last column of Table 4, the VIF values regarding regressors range from 1.18 to 3.21. These results also show that VIF values are well below the acceptable upper limit of 10 (Guajarati, 2004). As a consequence, we can deduce that the multicollinearity among the independent variables is not a serious issue in Equation (1). 
Table 4: Correlation Coefficients and Variance Inflation Factor (VIF) Values

\begin{tabular}{|c|c|c|c|c|c|c|c|c|c|c|c|c|}
\hline Variables & 1 & 2 & 3 & 4 & 5 & 6 & 7 & 8 & 9 & 10 & 11 & VIF \\
\hline (1) NPLs & 1 & & & & & & & & & & & - \\
\hline (2) BS & -.16 & 1 & & & & & & & & & & 1.95 \\
\hline (3) EQTA & $.26^{*}$ & $-.49 *$ & 1 & & & & & & & & & 1.50 \\
\hline (4) $\mathrm{ROA}$ & -.05 & $.25 *$ & $.35 *$ & 1 & & & & & & & & 1.91 \\
\hline (5) LTA & -.04 & .13 & $-.30 *$ & $-.27^{*}$ & 1 & & & & & & & 1.18 \\
\hline (6) PLLTA & $.50 *$ & .01 & -.06 & -.07 & $.34 *$ & 1 & & & & & & 1.93 \\
\hline (7) NII & $.26 *$ & $-.25 *$ & $.68^{*}$ & $.60^{*}$ & $-.36 *$ & -.02 & 1 & & & & & 1.69 \\
\hline (8) CRISIS & .10 & -.16 & -.01 & .15 & -.11 & -.08 & $.19 *$ & 1 & & & & 3.19 \\
\hline (9) INF & $-.19 *$ & -.05 & -.01 & .12 & -.001 & $-.22 *$ & .10 & .05 & 1 & & & 1.44 \\
\hline (10) GDP & $-.34^{*}$ & -.03 & -.12 & .04 & -.01 & $-.28 *$ & .07 & .08 & $.43 *$ & 1 & & 1.71 \\
\hline (11) UNEMP & $.26 *$ & -.10 & .12 & $.18^{*}$ & -.03 & .13 & .11 & $.73 *$ & -.12 & $-.28 *$ & 1 & 3.21 \\
\hline
\end{tabular}

Notes: Correlation coefficients of variables are significant at the $5 \%$ level or better. See Table 1 for variable definitions.

The results obtained from the traditional panel data models, i.e., the pooled-OLS, fixed-effects and random effects models are shown in Table 5. According to the results obtained from F-test, Breusch-Pagan's Lagrange multiplier (LM) test and Hausman specification test reported at the bottom of Table 5, fixed effects (FEs) estimator is preferred over random effect (REs) estimator and our model specified in Equation (1) is interpreted by using fixed effect (FEs) estimator. In Table 5 we report the coefficients of the explanatory variables and the corresponding t-statistics. We check the econometric properties of our specification in advance and report heteroskedasticity and autocorrelation consistent t-statistics on account of the existence of heteroscedasticity and autocorrelation.

According to the findings of empirical estimation of Eq. (1), bank capital (EQTA) has a positive impact on the rate of the NPLs in Turkish banks. In other words, higher capital ratio is related to higher rate of NPLs. We do not find evidence supporting Berger and DeYoung (1997)'s "moral hazard argument" that banks with thinner capital engage in more risky lending, resulting in an increase in the NPL ratio. This finding can attribute to the influence of regulatory pressure on the minimum level of Turkish banks' capital. The positive relationship between the EQTA and the NPLs rate is similar to previous banking studies (e.g., Ghosh 2015, Curak et al. 2013 and Godlewski, 2004). This result, however, is different from the findings of Abdioglu and Aytekin (2016), Ashraf et al. (2016), Bardhan and Mukherjee (2016) and Marki et al. (2014).

Regarding the relationship between ROA as a measure of bank profitability and the level of the NPLs ratio, it is negative and statistically significant at the $5 \%$ level. The negative sign of the ROA variable in the regression Equation (1) can be explained by the risk-taking behavior of banks' management. That is, banks with higher profitability ratios have less incentive to engage in more risky lending than the optimal level, which in turn results in lower non-performing loans rate. In case of Turkish banks, this finding supporting "bad management argument" that there is a negative association between past profitability and the NPLs are consistent with prior empirical results of Bardhan and Mukherjee (2016) for Indian banking system, Yagcilar and Demir (2015) for Turkish banking sector, Ghosh (2015) for the US banking sector, Baselga-Pascualet al. (2015) for European banking sector, Curak et al. (2013) for Southeastern European banking systems, Marki et al. (2014) for Eurozone's banking systems, Louzis et al. (2012) for Greek banking sector, Dimitrios et al. (2016) for euro-area banking system, Messai and Jouini (2013) for Italy, Greece and Spain and Boudriga et al. (2010) for commercial banks from 12 MENA countries.

The loan loss provisions ratio (PLLTA), which reflects asset quality and credit risk of deposit banks and defined as provisions for loan losses over total assets, has a positive and significant influence on the NPLs rate at the $10 \%$ level. The possible explanation for this result is that banks with poor credit quality could increase risk level of loan portfolio in their balance sheets. This estimation confirms the results obtained from prior banking studies (e.g., Boudriga et al., 2009; Chaibi and Ftiti, 2015; Ghosh, 2015; Messai and Jouini, 2013; among others).

Concerning the association between revenue diversification (NII) and nonperforming loans ratio, it is negative and significant at the $10 \%$ level. This means that a higher revenue diversification rate significantly contributes 
to lower the NPLs ratio. The negative impact of bank revenue diversification on the NPLs rate of banks allows us to accept Hu, Yang and Yung-Ho (2004)'s "diversification hypothesis" that less diversified banks have to rise the riskiness of their loan portfolio to generate profit, leading to an increase in the rate of NPLs. In terms of sign of this variable, the estimation result obtained is similar to the findings of Ghosh (2015) and Hu, Yang and YungHo (2004), but different from the studies of Louzis et al. (2012) and Chaibi and Ftiti (2015).

Table 5: Results of Panel Data Analysis

\begin{tabular}{|c|c|c|c|c|c|c|}
\hline \multirow[b]{2}{*}{ Explanatory variables } & \multicolumn{2}{|c|}{ Pooled OLS } & \multicolumn{2}{|l|}{ REs } & \multicolumn{2}{|c|}{ FEs } \\
\hline & Coefficient & t-Stat & Coefficient & z-Stat & Coefficient & t-Stat \\
\hline BS & -.0011 & -0.39 & .0028 & 1.22 & .0092 & 1.45 \\
\hline EQTA & .06987 & 0.67 & $.2229 *$ & 1.85 & $.2607 *$ & 1.94 \\
\hline ROA & -.2251 & -0.63 & $-.5372 * *$ & -2.19 & $-.5259 * *$ & -2.24 \\
\hline LTA & -.0269 & -0.76 & .0088 & .53 & .0237 & 0.68 \\
\hline PLLTA & $1.3155 * * *$ & 3.00 & $.7207^{* *}$ & 2.49 & $.7769 *$ & 1.85 \\
\hline NII & .3006 & 0.75 & -.1273 & -0.63 & $-.2508 *$ & -1.98 \\
\hline CRISIS & .0005 & 0.07 & $.0083^{*}$ & 1.72 & $.014 * *$ & 2.17 \\
\hline INF & .0526 & 0.58 & .0373 & .47 & .04465 & .56 \\
\hline GDP & $-.1452 * * *$ & -3.12 & $-.1404 * * *$ & -3.56 & $-.1326 * * *$ & -3.48 \\
\hline UNEMP & 1989 & 1.52 & .1514 & 1.50 & .0859 & .85 \\
\hline Constant & .0239 & 0.62 & -.0296 & -1.14 & -.0994 & -1.30 \\
\hline \multicolumn{7}{|l|}{ Results of diagnostic test } \\
\hline F-test & & & & & $11.54(.0000)$ & \\
\hline Breusch-Pagan LM test & & & $67.79(.0000)$ & & & \\
\hline Hausman test & & & & & $13.87(0.0312)$ & \\
\hline Autocorrelation & & & & & $14.414(.0013)$ & \\
\hline Heteroscedasticity & & & & & $51.02(.0001)$ & \\
\hline Adj. $R^{2}$ & 0.3277 & & 0.2735 & & 0.5420 & \\
\hline F-statistics & $13.50(.0000)$ & & & & $9.41(.0000)$ & \\
\hline Wald chi-squared & & & $94.34(.0000)$ & & & \\
\hline Observations & 114 & & 114 & & 114 & \\
\hline Banks in sample & 19 & & 19 & & 19 & \\
\hline
\end{tabular}

Notes: This table reports the determinants of the NPLs of Turkish banks over the period 2006-2012 using the traditional panel data estimators. Dependent variable is the ratio of non-performing loans to total loans. See Table 1 for definitions of the independent variables. The values in parentheses are probability values. All bank-specific indicators are lagged by one year to cope with endogeneity issue in our model specified in Eq. (1) and ***,**, and * indicate significance levels at 10, 5, and 1\%, respectively.

When the analysis results are evaluated with regard macroeconomic indicators, we can say that economic growth (GDP) is the most essential factor in determining the NPLs rate of deposit banks in Turkey. According to the results, a $1 \%$ percent rise in economic growth lowers the NPL ratio approximately by $0.13 \%$. The negative sign of this variable supports the findings of Kasman and Kasman (2015), Baselga-Pascualet al. (2015), Chaibi and Ftiti (2015); Makri et al. (2014); Nkusu, 2011; Castro (2013); Curak et al. (2013); among others. Finally, our results also reveal that NPLs ratio of deposit banks in Turkish banking system increases during the global economic crisis period. In other words, the crisis period covering the years 2008-2010 leads to a higher rate of non-performing loans. This finding is also in accordance with recent banking studies such as Us (2016), Kasman and Kasman (2015) and Castro (2013). Despite the fact that the effects of bank size (BS), loans-to-assets ratio (LTA), inflation rate (INF) and unemployment rate (UNEMP) on non-performing loans ratio are positive, the coefficients of these variables are statistically insignificant, implying that these variables have no effect on nonperforming loans ratio of deposit banks operating in Turkey during the sampling period.

\section{CONCLUSION}

The influence of bank-specific and macroeconomic factors on non-performing loan (loans under follow-up) is a widely explored research object for researchers, regulatory authorities and policy makers in the wake of the 
latest global economic crisis. This paper investigates the factors affecting non-performing loans ratio of 20 deposit banks in Turkish banking sector covering the period from 2006 to 2012 using traditional panel data analysis such as pooled ordinary least square, random effects and fixed effects estimates.

Our main results indicate that: (i) solvency ratio has a positive impact on the NPLs ratio; (ii) profitability measured by net income-to-total assets has a negative impact on the NPLs ratio; (iii) loan loss provisions has a positive impact on the NPLs ratio; (vi) revenue diversification measured by non-interest income-to-total assets has a negative impact on the NPLs ratio; (v) economic growth rate has a negative impact on the NPLs ratio; (vi) NPLs ratio increases during latest global economic crisis period.

There are lots of empirical studies focuses their attention on the NPLs matter because of the fact that the rise of non-performing loans (NPLs) is a remarkable characteristic of financial crises. The determining the rise of NPLs percentage in the banking systems is a vital issue in order to maintain financial/loans stability for the banks. The last global financial turmoil has re-emphasized the importance of the banking system problems in most advanced economies as well as emerging market economies. Banking system has some structural weakness such as NPLs, hazardous banking applications, moral hazard, bad loans, bad management, skimping in the last decades. These problems can weaken the banking system and cause payment difficulties. NPLs, impaired bank assets and their macroeconomic effects are the heart of financial stability problems. Hence, the solution of these problems is required for sustainable macroeconomics view, rapid economic activity, high economic performance, the creation of new jobs, and healthy financial stability. Otherwise, potential risks in banking system may occur a fall in the economic growth, increases of unemployment, high prices in the economy and banking crisis in the end.

For future research, various macroeconomic and bank specific variables and different estimators could be employed to explore the association between these variables and non-performing loans of banks. First, the effect of these factors on NPLs can be analyzed in deeper form for deposit banks in Turkey. Second, it may be worth expanding on the study of credit risk by using different kind of econometrics methods for Turkey. The results could be debated in terms of the findings of prior banking studies and related hypotheses.

\section{REFERENCES}

Abdioglu, N. \& Aytekin, S. 2016, "Assessing the factors that impact non-performing loan ratio: an application on deposit banks by using dynamic panel data", Journal of Business Research Turk, vol. 8, no. 1, pp. 538-555.

Aiyar, S., Bergthaler, W., Garrido, J.M., Ilyina, A., Jobst, A., Kang, K., Kovtun, D., Liu, Y., Monaghan, D. \& Moretti, M. 2015, “A strategy for resolving Europe's problem loans", IMF Staff Discussion Note, No. 15/19.

Ashraf, B.N., Arshad, S. \& Hu, Y. 2016, "Capital regulation and bank risk-taking behavior: evidence from Pakistan", International Journal of Financial Studies, vol. 4, no.3, pp. 1-20.

Bardhan, S. \& Mukherjee, V. 2016, "Bank-specific determinants of nonperforming assets of Indian banks", International Economics and Economic Policy, vol. 13, no.3, pp. 483-498.

Barseghyan, L. 2010, "Non-performing loans, prospective bailouts, and Japan's slow-down”, Journal of Monetary Economics, vol. 57, no. 7, pp. 873-890.

Baselga-Pascual, L., Trujillo-Ponce, A. \& Cardone-Riportella, C. 2015, “Factors influencing bank risk in Europe: evidence from the financial crisis",North American Journal of Economics and Finance, vol. 34, no. C, pp. 138-166.

Berger, A. \& DeYoung, R. 1997, "Problem loans and cost efficiency in commercial banks", Journal of Banking and Finance, vol. 21, no. 6, pp. 849-870.

Bholat, D., Lastra, R., Markose, S., Miglionico, A. \& Sen, K. 2016, "Non-performing loans: regulatory and accounting treatments of assets",Bank of England Staff Working Paper, No. 594.

Boudriga, A., Taktak, N.B. \& Jellouli, S. 2009, "Bank specific, business and institutional environment determinants of nonperforming loans: evidence from MENA countries", Economic Research Forum, Working Paper 547.

Castro, V. 2013, "Macroeconomic determinants of the credit risk in the banking system: the case of the GIPSI", Economic Modelling, vol. 31, no. C, pp. 672-683. 
Chaibi, H. \& Ftiti, Z. 2015, "Credit risk determinants: evidence from a cross-country study", Research in International Business and Finance, vol. 33, pp. 1-16.

Curak, M., Pepur, S. \& Poposki, K. 2013, "Determinants of non-performing loans - evidence from Southeastern European banking systems", Banks and Bank Systems, vol. 8, no. 1, pp. 45-53.

Demirguc-Kunt, A. 1989, “Deposit-institution failures: a review of empirical literature”, Economic Review, vol. 25, no. 4, pp. 2-18.

Demirguc-Kunt, A. \& Detragiache, E. 1998, “The determinants of banking crises and developed countries", IMF Staff Papers, vol. 45, no. 1, pp. 81-109.

Espinoza, R. \& Prasad, A. 2010, "Nonperforming loans in the GCC banking systems and their macroeconomic effects", IMF Working Paper, No. $10 / 224$.

Ghosh, A. 2015, "Banking-industry specific and regional economic determinants of non-performing loans: evidence from US states", Journal of Financial Stability, vol. 20, pp. 93-104.

Gujarati, D.N. 2004, "Basic Econometrics (4th ed.)", The McGraw-Hill Companies, Avenue of the Americas, New York.

Hu, J., Yang, L., \& Yung, H. C. 2004, “Ownership and non-performing loans: evidence from Taiwan's banks”, Developing Economies, vol. 42, no. 3, pp. 405-420.

İskenderoğlu, Ö. \& Tomak, S. 2013, "Competition and stability: an analysis of the Turkish banking system", International Journal of Economics and Financial Issues, Vol. 3, No. 3, pp.752-762.

Jakubik, P. \& Reininger, T. 2013, "Determinants of nonperforming loans in Central, Eastern and Southeastern Europe, focus on European economic integration", OesterreichischeNationalbank, vol. 3,pp. 48-66.

Jassaud, N. \& Kang, K. 2015, "A strategy for developing a market for nonperforming loans in Italy", IMF Working Paper, No. 15/24.

Kasman, S. \& Kasman, A. 2015, "Bank competition, concentration and financial stability in the Turkish banking industry", Economic Systems, vol. 39, no. 3, pp. 502-517.

Klein, N. 2013, “Non-performing loans in CESEE: determinants and impact on macroeconomic performance”, International Monetary Fund Working Paper, No. 13/72.

Louizis, D., Vouldis, A. \& Metaxas, V. 2012, "Macroeconomic and bank-specific determinants on non-performing loans in Greece: acomparative study of mortgage, business and consumer loan portfolios", Journal of Banking \& Finance, vol. 36,pp. 1012-1027.

Makri, V., Tsagkanos, A. \&Bellas, A. 2014, “Determinants of non-performing loans: the case of Eurozone”, Panoeconomicus, vol. 61, no. 2, pp. 193-206.

Messai, A.S. \& Jouini, F. 2013, "Micro and macro determinants of non-performing loans", International Journal of Economics and Financial Issues,vol. 3, no. 4, pp. 852-860.

Nkusu, M. 2011, "Nonperforming loans and macro financial vulnerabilities in advanced economies", International Monetary Fund Working Paper,No. 11/161.

Podpiera, J. \& Weill, L. 2008, "Bad luck or bad management? emerging banking market experience", Journal of Financial Stability, vol. 4, no. 2, pp. 135-148.

Reinhart, C. \& Rogoff, K. 2011, "From financial crash to debt crisis", American Economic Review, vol. 101, no. 5, pp. 1676-1706.

Sawada, M. 2013, "How does the stock market value bank diversification? empirical evidence from Japanese banks", Pacific-Basin Finance Journal, vol. 25, pp. 40-61.

Singh, A., \& Sharma, A.K. 2016, "An empirical analysis of macroeconomic and bank-specific factors affecting liquidity of Indian banks", Future Business Journal, vol. 2, no. 1, pp. 40-53.

Skarica, B. 2014, "Determinants of non-performing loans in Central and Eastern European Countries", Financial Theory \& Practice, vol. 38 , no. 1 , pp. 37-59.

Sorge, M. 2004, "Stress-testing financial systems: an overview of current methodologies", BIS Working Paper, No. 165.

Us, V. 2016, "Determinants of Non-Performing Loans in the Turkish Banking Sector: What Has Changed After the Global Crisis?", Ekonomi Notlari, No. 16/27:1-14.

Vardar, G. 2015, "Bank Competition, Concentration and Risk-Taking in the Turkish Banking Industry", Journal of Business, Economics and Finance, Vol. 4, No. 3, 536-567.

Yağcılar, G.G. \& Demir, S. 2015, "Determination of the factors effecting non-performing loans in Turkish banking sector", International Journal of Alanya Faculty of Business, vol. 7, no. 1, pp. 221-229.

Zeng, S. 2012, "Bank non-performing loans (NPLs): a dynamic model and analysis in China", Modern Economy, vol. 3, no. 1, pp. 100-110. 